IZA DP No. 4722

Wage Inequality, Linkages and FDI

Nigel Driffield

Sourafel Girma

Michael Henry

Karl Taylor

January 2010 


\title{
Wage Inequality, Linkages and FDI
}

\author{
Nigel Driffield \\ Aston University \\ Sourafel Girma \\ Nottingham University \\ Michael Henry \\ Aston University \\ Karl Taylor \\ University of Sheffield \\ and IZA \\ Discussion Paper No. 4722 \\ January 2010 \\ IZA \\ P.O. Box 7240 \\ 53072 Bonn \\ Germany \\ Phone: +49-228-3894-0 \\ Fax: +49-228-3894-180 \\ E-mail: iza@iza.org
}

Any opinions expressed here are those of the author(s) and not those of IZA. Research published in this series may include views on policy, but the institute itself takes no institutional policy positions.

The Institute for the Study of Labor (IZA) in Bonn is a local and virtual international research center and a place of communication between science, politics and business. IZA is an independent nonprofit organization supported by Deutsche Post Foundation. The center is associated with the University of Bonn and offers a stimulating research environment through its international network, workshops and conferences, data service, project support, research visits and doctoral program. IZA engages in (i) original and internationally competitive research in all fields of labor economics, (ii) development of policy concepts, and (iii) dissemination of research results and concepts to the interested public.

IZA Discussion Papers often represent preliminary work and are circulated to encourage discussion. Citation of such a paper should account for its provisional character. A revised version may be available directly from the author. 
IZA Discussion Paper No. 4722

January 2010

\section{ABSTRACT \\ Wage Inequality, Linkages and FDI}

This paper extends the existing literature on FDI and wage inequality. We do this in two ways. Firstly, we incorporate more precise measures of inward investment into the model, by allowing for differences in the effects between horizontal and vertical FDI. Secondly, after establishing the effects that inward investment has on wage inequality, we then analyse the reasons for this in terms of the wages paid to skilled and unskilled workers, and the effect that inward investment has on this. We illustrate the important differences that horizontal and vertical FDI have on both wages and wage inequality, and the importance of allowing for regional differences in the results. FDI nationally tends to increase wage inequality, while the local, effects are opposite. FDI into assisted areas tends to increase wage inequality nationally, when the MNEs purchase inputs in the local region.

JEL Classification: F21, F23, J31

Keywords: $\quad$ wage inequality, FDI spillovers, backwards and forwards linkages

Corresponding author:

Nigel Driffield

Aston Business School

Aston University

Aston Triangle

Birmingham B4 7ET

United Kingdom

E-mail: n.I.driffield@aston.ac.uk

\footnotetext{
* This paper contains statistical data from the ONS which is Crown copyright and reproduced with the permission of HMSO and Queen's Printer for Scotland. The use of the ONS statistical data in this paper does not imply the endorsement of the ONS with respect to the interpretation or analysis of the statistical data. The authors wish to acknowledge the support of the ESRC under award number RES000-22-0468.
} 


\section{Introduction}

Over the past two decades a number of studies have documented the relative decline in unskilled wages for a number of countries, see Katz and Autor (1999) for a comprehensive review. The general consensus is that this has resulted from increasing demand for higher skilled labour. This phenomenon has occurred within industries and narrowly defined skill groups in the US and UK, Katz and Autor (1999), Taylor (2006). The two most common explanations behind such a demand shift are exogenous and endogenous technological change, biased in favour of skilled labour and growing international trade (Acemoglu, 2002). ${ }^{1}$

Both trade and the pace of technological change have arguably accelerated over the past two decades, however foreign direct investment (FDI) by multinational enterprises (MNEs) both into and out of the UK has also grown at a rapid rate in recent years, such that investment by foreign firms has accounted for approximately $28 \%$ of total manufacturing investment in the $\mathrm{UK}^{2}$. Equally, as Machin and Van Reenen (1998) and others have reported, wage inequality has increased over the period, not just in the UK but internationally.

This paper proceeds as follows: Section 2 presents both the theoretical and empirical analysis of the links between FDI and wages / wage inequality. Section 3 presents the theoretical model, and the decomposition of the wage effects. Section 4 presents the data, and section 5 discusses the estimation in some detail. The final sections offer some discussion of the results and some conclusions.

\section{IIi. Theoretical analysis of FDI and wage inequality}

As we discuss below in detail, there is very little formal theoretical analysis of the impact of inward investment on wage inequality. Rather, the empirical literature that exists relies on the more conceptual literature that seeks to explain FDI in terms of technology differences

\footnotetext{
${ }^{1}$ Note other potential causes of wage inequality capable of explaining within industry changes are: skill biased occupational changes, Caroli and Van Reenen (2001); relative supply shifts with a fall in the growth rate of educational attainment amongst cohorts born after the 1950s, Card and Lemieux (2000) and Gosling et al. (2000); and institutional changes such as weakening union strength, Machin (1997).

${ }^{2}$ Authors' calculations based on ABI data, various years
} 
between the host sector and the inward investors, or the wholly empirical "trade versus technology" debate. However, there are more formal treatments that can inform our study. For example, in a different context Bresnahan (1999) argues that computer use, and the subsequent impact of "white collar" productivity explains wage inequality in the West, while others discussed below focus on the trade issue, and the bidding down of unskilled wages.

Perhaps the best known theoretical treatment of inward investment and linkages is Rodriguez-Clare (1996). This shows that where inward investors purchase inputs from indigenous suppliers, then the developmental effects of this inward investment are all the greater. Rodriguez-Clare (1996) relates the extent of linkages between inward investors and domestic firms to the cost of communication between the head office of the MNE and the local subsidiary. Markusen and Venables (1996) extend the theoretical basis for the importance of agglomeration, showing that inward investment into a region will not only stimulate domestic activity, but that this domestic development may eventually replace the original FDI. There are, to the best of our knowledge no formal extensions of this that examine wage dispersion or inequality explicity, either in terms of direct or indirect effects. However, there are theoretical treatments of the impacts of FDI more generally. Wang and Blomstrom (1992) for example present a model of technology transfer from FDI, and show that effort is required by recipient firms, in the form of human capital. This suggests that workers with more human capital will appropriate more of the beneficial effects of FDI than unskilled workers. An extension to this is provided by Zhao (1998), who presents a model that examines the impact of FDI on wages and employment more directly. By focussing on the firm specific nature of FDI, Zhao (1998) shows that inward investment provides more scope for union bargaining at the firm level, such that the union can bargain with more firms, and hence wages rise. An assumption of this model however is that full employment prevails, such that again the relative effects of FDI on different types of workers depend on the relative 
supply of the different types of labour. The inference from Zhao (1998) being that inward FDI benefits those workers with greater bargaining power.

This is related to the theoretical literature concerned with explaining FDI flows, see for example recent work by Braconier et al. (2005) and Mugele and Schnitzer (2006) which highlights the importance of considering "vertical" as well as horizontal FDI. In the theoretical literature, this means relating the location of internationally mobile activities to the relative cost of production, but this can be extended. Rather than simply considering the internal cost of production, it is also necessary to consider the local production by the inward investor, and local purchasing and selling by the inward investor in terms of the effects of FDI. This result is dependent on linkage effects, but the impact of FDI and input-output linkages has not been explored in the context of wage inequality, as equally the inter-regional effects of transaction linkages on relative wages also remain unexplored.

The more formal treatments of wage dispersion or inter-industry wage differentials tend to focus on search theory to explain these apparent differences across industry Montgomery (1991). This literature stresses two important concepts in explaining wage differentials. The first is heterogeneity, specifically at the firm level when explaining intraindustry differences. The second, and perhaps more important in many of the theoretical treatments is the search behaviour, of both firms and workers. For example, as Montgomery (1991) shows, the probability of a firm filling a given vacancy with a worker of appropriate skills, is endogenously determined with the wage that the firm decides to offer. Montgomery shows formally that even in a thick homogenous labour market, the search behaviour required to fill a given vacancy will lead to wage inequality. When one considers the earlier treatments of this problem by Lang (1991) or Weitzman (1989) that show the importance of firms offering higher wages to increase the probability of hiring, the links to the formal theories of FDI discussed above becomes more apparent. Acemoglu (1999) builds on the search theory 
approach. Acemoglu's (1999) treatment includes the notion of skill based technical change, causing a change in the job composition and therefore a greater return for (scarce) skilled workers. Acemoglu (1999) however extends this argument more formally to include searching behaviour. Where search (by either the firm or the worker) is costly, firms also engage in more screening behaviour, focussing on the best candidates, and in turn "casting their net wider". In terms of a model of the UK labour market, this suggests that inter-regional effects will be greater for skilled workers than unskilled ones. Postel-Vinay and Robin (2002) show how a search model, including on-the-job search will lead to wage dispersion, even between homogeneous workers. They show that the worker specific match to a firms productivity is the main driver of earnings of workers, with workers who believe that they are "under matched" seeking a better match while in employment. This is consistent with much of the evidence on the impacts of FDI on labour markets (for a discussion of this literature see Driffield and Taylor, 2000) that suggests where inward investors recruit (for a greenfield site for example) they do not recruit from the pool of unemployed, but from the employed. This increases labour market competition, especially for skilled workers. This is consistent with the findings of Groshen (1991) who shows that a big driver of wage dispersion is the firm level characteristics. This again confirms earlier studies of inward investors, suggesting that they pay higher wages due to their higher productivity.It should be noted here that the formal explanations or theoretical treatments of wage inequality focus on explaining differences in earnings between seemingly homogeneous workers. These all point towards firm level characteristics as being key drivers of wage differentials, with the search costs borne by the individuals. Recently, Mortensen (2009) demonstrates that a crucial factor in the theoretical treatment of wage dispersion is firm heterogeneity, and the positive cross firm correlation between wages and productivity. This is important when looking at the impact of new (foreign owned) entry on wage inequality. In a market encompassing heterogeneous firms, 
and focussing on the impact of inward investors, this search process becomes more important. Most theories of FDI (see for example Dunning, 1979) focus on the uncertainty associated with entering a foreign market. In such circumstances, the search behaviour of both the firm and the employee becomes even more important.

The rather small theoretical literature discussed here has a further limitation, in that it ignores the endogeneity of FDI. Increased wage inequality is generally associated with labour market flexibility, on the basis that labour market flexibility increases the relative return to skilled workers. This occurs through inter-industry and regional mobility, but also it is argued that skilled workers are better able to reallocate activity and respond to shocks. Javorcik and Spatareanu (2005) show that location choice, and the volume of FDI are positively related to labour market flexibility in the host country and to the difference between labour market regulations in the host and the source countries. A more flexible labour market in the host economy (relative to the investor's home country) is associated with a higher likelihood of investment. As such therefore, it is likely that inward investment is attracted to the UK due to its relatively high level of labour market flexibility, and that this is associated with an increased demand for low skill (low wage) workers.

\section{IIii. Empirical analysis of FDI and wage dispersion and some extensions}

Previous studies, see Greenaway and Nelson (2001) for a survey, have shown that inward investment bids up skilled wages in the domestic sector, thus increasing wage inequality, not only in the region of the investment, but in the surrounding regions. This is an important issue for policy makers, as concern has been expressed that both skill shortages and labour market tightening have been exacerbated in certain parts of the country by inward investment.

While there are a growing number of studies that look at the impacts of foreign acquisition on wages or wage inequality, see for example Girma and Görg (2007) or Huttenen (2007), to our knowledge there has not been any systematic investigation into the impact of 
FDI upon growing UK wage inequality which highlights regional effects as well as the influence of forward and backward linkages. Work examining the aggregate effects of FDI upon wage inequality include: Taylor and Driffield (2005) for the UK; Figini and Gorg (1999) for Ireland; Blonigen and Slaughter (2001) for the USA and Bandick and Hansson (2005) for Sweden. In response, this paper examines the impact of inward FDI upon relative wages in UK manufacturing industries employing highly disaggregated firm level data and makes the contribution of examining both the regional and industry level effects of FDI on wage inequality, and also considers forward and backward linkage inter-industry effects.

Previous work has pointed to FDI acting to increase wage inequality within the industry concerned, (e.g. Taylor and Driffield, 2005, Figini and Görg, 1999). The explanation for this is two fold, based on both technology and labour market effects (Driffield and Girma, 2003). The analysis for backwardly linked FDI is therefore similar. Inward investors purchasing inputs from domestic producers is associated with technology transfer, and is therefore likely to increase the returns to skilled workers in those sectors. Görg and Strobl (2002) for example relate entry by domestic firms to inward investment, ascribing this to linkage effects, though the implications for wage inequality are less clear. The more recent outsourcing literature suggests that inward investors purchasing from upstream suppliers may be increasing the relative demand for unskilled workers in those industries, as they seek to buy in low skill inputs. In such cases, backwardly linked FDI could reduce wage inequality in upstream sectors.

Finally, forward linkages and FDI (foreign firms selling to the domestic sector) have seldom been examined in any context. Driffield et al. (2003) associate this with productivity growth in the downstream domestic sector, but the impacts on wage inequality are less clear. In terms of the literature on FDI flows, inward investors in the UK that are seeking to sell domestic companies could be labelled as "market seeking”. Such FDI is generally associated 
with crowding out effects rather than spillover effects, so the relative wage effect may be moderate compared with the absolute employment effect.

The regional dimension is expected to be important here and has previously been overlooked. The literature on wage spillovers suggests that the labour market effects of capital investment or external wage changes are relatively limited geographically, so we expect different effects within the locality of the investment compared with national effects. Such differences are compounded by the fact that many purchasing relationships between inward investors and domestic firms tend to be local, while industry level crowding out effects for example are more likely to be national.

However, the labour demand effects cannot be ignored. While theoretical motivations for FDI tend to focus on technology differences between home and host country firms, relative labour costs are also important. The UK has attracted a high proportion of FDI into Europe despite being an R\&D intensive country, because it has (by European standards) flexible labour markets, while many regions of the UK are characterised by relatively low wages. As such, some inward investors attracted to the UK because of relatively low wages may tend to increase demand for relatively unskilled labour, and potentially reduce wage inequality (see for example, Driffield et al. (2009)).

There is a further consideration within the regional dimension. A large proportion of the new inward investment into the UK is attracted to the less advantaged regions of the UK, and attracts some form of subsidy within the assisted areas framework. Further, such investments are subsidised on the basis that they will generate a given number of new jobs for the region, so inward investment into such areas may be expected to have different labour market effects from investment elsewhere. Much of the traditional analysis here has focussed on "backward" linkages from inward investors, that is the foreign firms purchasing inputs from domestic firms. In such cases, much of the evidence suggests that this will have the 
effect of increasing the demand for unskilled labour in the supplying industry, and reducing wage inequality.

It is therefore necessary to distinguish between FDI into assisted areas and nonassisted areas. Investment into assisted areas is eligible for subsidies, on the basis that it generates employment in regions with significant structural unemployment. As such, factor demand by inward investors in assisted areas is likely to differ from that in non-assisted areas. Indeed, our results show that inward investment into assisted areas increases the demand for unskilled workers and reduces wage inequality. This effect is strongest for low skill industries, such that these effects are motivated by a simple increase in unskilled jobs, rather than by any dynamic effects such as technology spillovers or upskilling.

\section{The Model}

To identify the link between inward FDI and within-industry shifts in demand towards higher skilled labour, we exploit variations in FDI across manufacturing industries and between years. The theoretical framework is based upon a flexible translog cost function, following Berman et al. (1994). Industry $i$ and the firms $f$ within the industry are assumed to have cost functions of the following form:

$$
\begin{aligned}
& \ln C_{i}=\alpha_{0}+\alpha_{Y} \ln Y_{i}+\frac{1}{2} \alpha_{Y Y} \ln Y_{i}^{2}+\beta_{K} \ln K_{i}+\frac{1}{2} \beta_{K K} \ln K_{i}^{2}+\sum_{j} \gamma_{j} \ln W_{i j} \\
& +\frac{1}{2} \sum_{j} \sum_{l} \gamma_{j l} \ln W_{i j} W_{i l}+\sum_{j} \delta_{Y J} \ln Y_{i} \ln W_{i j}+\sum_{j} \delta_{K J} \ln K_{i} \ln W_{i j}+\rho \ln Y_{i} \ln K_{i}+\lambda_{T} \ln \boldsymbol{T}_{i} \\
& +\frac{1}{2} \lambda_{T T} \ln \boldsymbol{T}_{i}^{2}+\lambda_{T Y} \ln \boldsymbol{T}_{i} \ln Y_{i}+\lambda_{K T} \ln \boldsymbol{T}_{i} \ln K_{i}+\sum_{j} \phi_{T J} \ln \boldsymbol{T}_{i} \ln W_{i j}
\end{aligned}
$$

where $C$ represents variable costs, $Y$ is output, $K$ is the capital stock, $W$ is the price of the variable factor $j$, and $\boldsymbol{T}$ is a vector of possible demand shifters e.g. technology. Since cost is homogeneous of degree one in prices then $\sum_{l} \gamma_{i l}=\sum_{j} \gamma_{i l}=\sum_{j} \delta_{i l}=\sum_{j} \delta_{Y j}=0$ hence 
normalising on one of the factor prices and applying Shepard's lemma two factor shares $S$ can be derived - skilled and unskilled labour:

$$
S_{i j}=\alpha_{j}+\delta_{Y j} \ln (Y)_{i}+\delta_{K j} \ln (K)_{i}+\gamma \ln \left(W_{j} / W_{l}\right)+\phi_{T j} \ln (T)_{i}
$$

Hence the empirical model, estimated for domestic firms only $(f)$ operating in region $(r)$, within the industry $(i)$ over time $(t)$ is as follows:

$$
\ln \left[\frac{W_{S K}}{W_{S K}+W_{U N S K}}\right]_{\text {firt }}=\Omega+\alpha \ln (K)_{\text {firt }}+\beta \ln (Y)_{\text {firt }}+\pi(\boldsymbol{T})_{\text {irt }}+\varepsilon_{\text {firt }}
$$

where the dependent variable is the log share of skilled wages in the total wage bill. ${ }^{3}$ In particular we are interested in examining the impact of FDI upon wage inequality experienced in UK owned firms. The simplest model to estimate would be one where the vector of demand shifters $\boldsymbol{T}$ is replaced by proxies for, technological change, Tech, international trade, Trade, controls for the degree of product market competition such as concentration and market share, contained in $\boldsymbol{Z}$, (where larger firms may have higher wages due to the employer size wage effect, Green et al., 1996), and our primary variable of interest multinational activity, $F D I$ :

$$
\begin{aligned}
& \ln \left[\frac{W_{S K}}{W_{S K}+W_{U N S K}}\right]_{\text {firt }}=\Omega+\alpha \ln (K)_{\text {firt }}+\beta \ln (Y)_{\text {firt }}+\lambda \ln (\text { Tech })_{i t} \\
& +\phi \ln (\text { Trade })_{i t}+\mu \ln (F D I)_{i r t}+\boldsymbol{\tau}^{\prime} Z_{\text {firt }}+\varepsilon_{\text {firt }}
\end{aligned}
$$

Such an approach is similar to that taken by Taylor and Driffield (2005) based upon disaggregated industry level data.

However, the key contribution that this paper makes is that we are able to consider the effects of FDI in greater detail than previous analysis. Specifically, when seeking to evaluate the effects of FDI on wage inequality, we make use of several stratifications of the data.

\footnotetext{
${ }^{3}$ Note that relative wage rate for the two types of labour $\left(W_{j} / W_{l}\right)$ is dropped due to the possible introduction of bias into the estimates as these terms are directly involved in the construction of the dependent variable, this is consistent with other work (Berman et al., 1994).
} 
Firstly, we distinguish between local and national effects, by utilising the regional dimension to the data, and also allowing for the effect of distance between the inward investors located in the UK and the reference plant. Secondly, FDI is classified at the 3 digit level, to allow for both inter- and intra industry effects, and thirdly we employ input-output matrices to identify whether industries buy or sell from each other, to identify backward or forward FDI. We adopt the convention that "backward linked" FDI is inward investment that purchases inputs from domestic producers. Our final estimating equation is thus:

$$
\begin{aligned}
& \ln \left[\frac{W_{S K}}{W_{S K}+W_{U N S K}}\right]_{\text {firt }}=\Omega+\alpha \ln (K)_{\text {firt }}+\beta \ln (Y)_{\text {firt }}+\lambda \ln (\text { Tech })_{i t}+\phi \ln (\text { Trade })_{i t}+ \\
& \varphi_{1} \ln (F D I)_{i r t-1}+\varphi_{2} \ln (F D I)_{i s t-1}+\varphi_{3} \ln \left(B W D_{-} F D I\right)_{j r t-1} \\
& +\varphi_{4} \ln \left(F W D_{-} F D I\right)_{j r t-1}+\varphi_{5} \ln \left(B W D_{-} F D I\right)_{j s t-1}+\varphi_{6} \ln \left(F W D \_F D I\right)_{j s t-1}+ \\
& \boldsymbol{\tau}^{\prime} \boldsymbol{Z}_{\text {firt }}+\varepsilon_{\text {firt }}=\psi^{\prime} \boldsymbol{X}_{\text {firt }}+\varepsilon_{\text {firt }}
\end{aligned}
$$

where the subscript $j(i \neq j)$ represents inter industry and the subscript $s$ means outside region $(r \neq s)$ i.e. inter regional. Variables other than those defined above are $F W D_{-} F D I$ and $B W D_{-} F D I$ representing forward and backward linkages. Those variables which capture inter-regional effects are weighted by the square of the distance between regions. Incorporating the subscripts we have:

$(F D I)_{i r t-1} \quad$ Intra industry FDI in the same region

$(F D I)_{i s t-1} \quad$ Intra industry FDI in outside region

$\left(B W D D_{-} F D I\right)_{j r t-1} \quad$ Inter industry backward FDI in the same region

$\left(F W D_{-} F D I\right)_{j r t-1} \quad$ Inter industry forward FDI in the same region

$\left(B W D D_{-} F D I\right)_{j s t-1} \quad$ Inter industry backward FDI outside region

$\left(F W D_{-} F D I\right)_{j s t-1} \quad$ Inter industry forward FDI outside region 
Decomposing the wage inequality effects.

In order to disentangle the impacts of FDI upon the different skill groups ( $g$ ) we also estimate wage levels equations for skilled and unskilled workers, akin to Berndt (1991) and Hijzen et al. (2005) .

$$
\ln \left(W^{g}\right)_{\text {firt }}=\psi^{\prime} \boldsymbol{X}_{\text {firt }}+\varepsilon_{\text {firt }}
$$

We employ a relatively standard GMM-IV estimation here to allow for the endogeneity, not just of the capital and output terms, but also of the FDI terms. The analysis of wage inequality in the literature essentially treat the "impact" variable, such as trade, technology of FDI as an exogenous shock, see for example Acemoglu (2002). This is valid within a model of wage inequality, or at least an empirical issue to be tested. However, in models of wage determination, it is possible that for example FDI may be attracted to locations with low wages, or to locations where new investment is unlikely to bid up wages. We therefore estimate the wage equations for both skill-groups, incorporating the full set of inward investment terms. This has the advantage in that one might expect structural changes such as technology, trade and FDI to have differing impacts upon skilled and unskilled labour. For example, intra industry backward FDI in the same region, assuming that FDI is complementary to skilled labour, would be expected to increase skilled wages and decrease unskilled wages.

\section{The Data}

All of the data for this study, with the exception of the input-output, R\&D and trade data, are taken from the Annual Respondents Database (ARD) which is housed at the Office for National Statistics (ONS). We focus on the years 1980-1995, after which the distinction between skilled and unskilled workers is not made in the data. In terms of identifying linkages, we follow the convention employed in the regional science and input-output literature, and use input-output tables for the various years. The use of input-output tables in 
this way to identify linkages between inward investors and domestic firms is discussed in detail in the context of FDI linkages in Smarzynska-Javorcik (2004), in terms of intermediate inputs in Hijzen et al (2005) and in a regional science context in Driffield et al (2006), who also highlight the assumptions required to employ nationally derived input-out tables with regional data. We follow the standard convention and define "backwardly linked" inward investment, as the case where the inward investor is upstream from the UK sector, that is that it is an industry that purchases intermediate inputs from another identifiable sector. Forward linkages by contrast arise when the inward investor sells intermediate output to another identifiable sector. Of course, a particular investment can be both backwardly and forwardly linked to different sectors simultaneously.

The ARD contains micro-level data on variables including gross output, employment, investment and intermediate goods expenditure, collected by the ONS from its mandatory annual survey of UK businesses known as the Annual Census of Production until 1998, and now the Annual Business Inquiry (ABI). Detailed descriptions of this data are provided by Griffith (1999), Oulton (1997), Barnes and Martin (2002) and Harris (2002) among others. Consequently, only a brief discussion of the data is given here. ${ }^{4}$ The summary statistics for the internal and external variables are provided in table A1, while the regional distributions of inward investment are given in table A2. These highlight significant differences in inward investment penetration across regions. Table A2 highlights the almost bi-modal distribution of inward FDI in the UK, focussed on the richest regions of the UK, and the poorest. This highlights the importance of determining the within, and between region effects when examining the impacts of FDI, and also allowing for the distinction between assisted and nonassisted regions of the UK.

\footnotetext{
${ }^{4}$ These data are discussed in detail in numerous papers, see for example Haskel and Heden (1999), Girma and Wakelin (2001), Oulton (2001) and Griffith and Simpson (2002). Equally, these authors discuss the sampling of the ARD. Firms with more than 100 employees are always sampled while smaller businesses are sampled randomly. As Criscuolo and Martin (2005) outline, these are in effect plant level data.
} 
Input-output tables, as well as the $\mathrm{R} \& \mathrm{D}$ and trade data used in computing the technology and trade intensity measures were obtained from the ONS. These data were then matched with the ARD data at the 3-digit industry level.

\section{Estimation}

Our preferred estimator for estimating Equation (5) is the feasible efficient two-step instrumental variable (IV) GMM estimator (see Hansen, 1982). This estimator was chosen as the primary estimator largely because of the potential endogeneity of at least two of the regressors - namely capital and real gross output - which may result in biased and inconsistent estimates of the true parameters. Additionally, the instrumental variable GMM estimator is more efficient than the conventional IV two-stage least squares estimator in the presence of heteroscedasticity of unknown form. If heteroscedasticity is present, then the conventional IV estimator although consistent, is inefficient. ${ }^{5}$

Lagged values of capital and real gross output were used as instruments for the likely endogenous regressors. The validity (or lack of it) of these instruments are checked using the Hansen $\mathbf{J}$ test of over-identification. Additionally, we allow for unspecified correlation of error terms within groups (i.e. plants) but not between groups. Although the GMM method has the advantage of controlling for potential endogeneity, it can only identify conditional mean effects, and could be susceptible to the problem of outliers.

Accordingly, we also estimated our model using two techniques that are robust to this problem: outlier robust and median regressions. ${ }^{6}$ The results from these estimators are similar to the results reported, so for brevity are not included.

\footnotetext{
${ }^{5}$ It should also be noted that the problems posed by heteroscedasticity for the traditional IV estimator can only be partially resolved through the use of heteroscedasticity-consistent or "robust" standard errors and statistics (Baum, Schaffer and Stillman, 2003)

${ }^{6}$ The underlying thrust of this estimation procedure is to characterise the most coherent part of the data and thus restrict the influence of small groups of observations not representative of the rest of the sample (Temple, 1998). These results are available on request from the authors.
} 
Further, it is possible that the empirical methodology that we employ does not enable us to fully capture the likely differential effects that FDI has on the wages of skilled and unskilled workers respectively. As an alternative (indirect) estimation approach we therefore estimate separate wage regressions, using the GMM-IV approach for these two groups of workers and infer the differential impacts of FDI on wages from the results. For consistency, the wage equations are similar to the specifications employed above, following the analysis of Hijzen et al. (2005).

\section{Results}

Table 1 demonstrates the results of the impact of FDI on wage inequality, based on the estimation of (5) across the various specifications of the model. Market share and industry concentration are strongly correlated with wage inequality. Concentrated industries exhibit higher levels of wage inequality, while firms with higher market shares exhibit lower levels of wage inequality. This is in line with the applied industrial economics literature following Sutton $(1996,1998)$ that suggests that concentrated industries have high levels of capital and new technology. The literature discussed above would then suggest that skilled workers in such sectors have much higher levels of productivity, with therefore higher levels of wage inequality. At the same time, one would expect a degree of rent sharing within the leading firms, see for example Blanchflower et al (1996).

In contrast to more aggregate studies in the labour market impacts of FDI, (Figini and Görg, 1999, Taylor and Driffield, 2005) that find that nationally the horizontal effects of inward investment are to increase wage inequality, the baseline model shows no significant intra-industry national effect on wage inequality of inward investment. Backwardly linked FDI acts to reduce wage inequality at a national level, while there is weak evidence of an increase locally. This again highlights the two opposite effects here. Inward investment that purchases from domestic industry nationally tends to increase the demand for unskilled 
workers in the upstream sector, as a result perhaps of outsourcing some low value added activities to local producers. Any technology effect of backward linkages leading to greater wage inequality is limited to the region of the investment.

Model 2 includes the technology (R\&D) and trade effects. The findings discussed above are robust to the inclusion of both trade and technology in the model, and in general the effects of imports on wage inequality are insignificant. We also experimented with imports into upstream and downstream sectors, though this again proved insignificant.

Of more interest are the results reported in Model 3, offering a comparison of assisted areas with non-assisted areas. The importance of backwardly linked FDI clearly differs between assisted areas and non-assisted areas, in that FDI into an assisted area that then purchases from local firms acts to reduce wage inequality, while in other areas it acts to increase it. This is an important result, and is consistent with development policy with respect to poorer areas of the developed world. Encouraging FDI into assisted areas increases the demand for unskilled labour locally, thus reducing inequality. This highlights the heterogeneous effects of inward investment into the UK, and indeed heterogeneity in FDI generally. MNEs are attracted to assisted areas through subsidies, and through the availability of large amounts of unskilled labour. As such, firms of this type that then source inputs locally are likely to be sourcing low value products, which requires more unskilled labour. Conversely, firms entering other parts of the country are attracted by levels of indigenous development, and seek to employ more skilled labour - and potentially seeking inputs produced by skilled labour. In such cases inward investment then acts to increase wage inequality rather than reduce it. Interestingly, FDI in an assisted area, that is backwardly linked also has a national effect. This suggests that inward investment into the poorer areas of the UK also has a "crowding out" effect, in that it reduces the demand for skilled workers elsewhere, thus increasing wage inequality. To further explore this, we carried out various 
tests of equality of coefficients across assisted and non-assisted areas. These are presented in table 2. One can reject the hypothesis that upstream FDI within the region has the same impact on wage inequality in assisted and non assisted areas. Also that the coefficients on backwards FDI nationally are different for assisted an non assisted areas. As such backwardly linked FDI within a region increases wage inequality, while backwardly linked FDI in assisted areas reduces it. The reverse however is true for the interregional effects. Downstream FDI however has no asymmetric impact $(\mathrm{p}=0.179)$. These findings are robust to the inclusion of the trade variables presented in model 4.

Turning now to the estimation of the wage equations for skilled and unskilled domestic workers respectively, the results are shown in Table 3. These models allow us to consider whether FDI (or technology/trade) effects are specifically influencing either skilled and/or unskilled wage, which is not directly discernible from the wage inequality estimates. The wage equations are estimated employing a standard GMM IV estimator to allow for the potential endogeniety of the covariates. Technology, as proxied by $R \& D$, has a positive influence upon skilled wages at the 5\% level. This implies that skill bias technological change as does export intensity consistent with the evidence found for the US by Bernard and Jensen (1997). Conversely, import intensity has a negative association with both skilled and unskilled wages implying a potential role for outsourcing. This sheds some light on the literature discussed above, in that both technology and trade are associated with wage inequality, but the evidence suggests that these factors are operating via different routes. Interestingly, the positive effects of technology and export intensity, where significant, are smaller in absolute magnitude than those stemming from import intensity, consistent with the finding of Taylor and Driffield (2005) based upon aggregated industry level data. FDI in upstream sectors reduces the earnings of unskilled workers, but has no significant impact on the earnings of skilled workers. This is consistent with the results for the wage inequality models, and 
suggests that the mechanism by which inward investment increases wage inequality, is not so much by rewarding skilled workers, as by causing the earnings of unskilled workers to be bid down.

The second set of models illustrate the differences across type of region. Inward investment into assisted areas has a positive but insignificant effect on skilled wages, and a negligible negative effect on unskilled wages. However, FDI into assisted areas, that then sells to UK firms, has an additional negative effect of unskilled wages (and a smaller and insignificant negative effect on skilled wages), not merely in the immediate area but nationally. This is consistent with the wage inequality results presented above, and again highlights the heterogeneous nature of FDI, and of its effects, which typically is ignored in econometric work. Finally, model 4 includes both the assisted areas terms, and the trade and technology terms, illustrating that the inferences from the earlier specifications are robust to these inclusions.

\section{Conclusion}

This paper has highlighted several hitherto unexplored findings with respect to the labour market effects of inward investment. Firstly, that inward investment into a country such as the UK is heterogeneous, and therefore to treat "inward investment" as a homogeneous block of capital is erroneous. In general, supporting previous work in this area, we find that FDI does act to increase wage inequality at the national level, while the local effects are often different from the national effects. This is an important result for policy makers concerned with regional development. A concern for some time has been that globalisation, and the FDI component of it has acted to increase inequality by increasing the relative return to skilled labour. In common with previous work, we find evidence of this, but also that regional policy mitigates against this. Inward investment into assisted areas acts to increase the demand for unskilled workers, generating employment and reducing inequality. This is consistent with the 
aims of policies such as Regional Selective Assistance (RSA) or Selective Finance for Investment (SFIE).

However, FDI into non-assisted areas is generally associated with international technology transfer, and interactions between firms engaged in more high value added activities. The introduction of new technology by inward investors acts to increase the returns on skilled labour, and increase inequality. However, this type of investment has also been associated with so called "trickle down" patterns of development, in that such firms outsource a lot of their low value added activities, thus increasing demand for unskilled labour elsewhere. We find some support for this, in that backwardly linked inward investment generates a reduction in wage inequality at the national level, while increasing it at the local level, through technology transfer and spillovers.

This paper therefore highlights the importance of considering linkages, not just in terms of technology transfer or spillovers, but in labour market effects. Much of the work carried out on the labour market effects of trade or investment have simply looked at horizontal, or intra-industry relationships, while this work has shown that the inter-industry, and indeed inter-regional effects are potentially greater. 


\section{References}

Acemoglu, D. (1999) 'Changes in Unemployment and Wage Inequality: An Alternative Theory and Some Evidence.' American Economic Review, 89, 1259-78.

Acemolgu, D. (2002) 'Technical Change, Inequality and the Labor Market.' Journal of Economic Literature, XL, 7-72.

Aghion, P. and Howitt, P. (1998) Endogenous Growth Theory. Cambridge, MA: MIT Press.

Arellano, M. and Bond, S. (1991) 'Some Tests of Specification for Panel Data: Monte Carlo Evidence and an Application to Employment Equations.' Review of Economic Studies, $58,277-97$.

Berman, E., Bound, J. and Griliches, Z. (1994) 'Changes in the Demand for Skilled Labour within US Manufacturing Industries.' Quarterly Journal of Economics, 109, 367-98.

Bernard, A., Jensen, J., 1997. 'Exporters, Skill Upgrading and the Wage Gap.' Journal of International Economics, 42, 3 -31.

Blanchflower, D, Oswald, A and Sanfrey, P. (1996) 'Wages, Profits and Rent Sharing.' Quarterly Journal of Economics, 111, 227-51.

Blonigen, B. and Slaughter, M. (2001) 'Foreign-affiliate Activity and US Skill Upgrading.' Review of Economics and Statistics, 83, 362-76.

Bresnahan, T.F. (1999) 'Computerisation and Wage Dispersion: An Analytical Reinterpretation.’ The Economic Journal, 109, F390-F415.

Caroli, E. and Van Reenen, J. (2001) 'Skill-biased Organizational Change? Evidence from a Panel of British and French Establishments.' Quarterly Journal of Economics, 116, 1449-92.

Driffield, N. and Girma, S. (2003) 'Regional Foreign Direct Investment and Wage Spillovers: Plant Level Evidence from the U.K Electronics Industry.' Oxford Bulletin of Economics and Statistics, 65, 453-74.

Driffield, N.L. Munday, M. and Roberts, A. (2004) 'Inward Investment, Transactions Linkages, and Productivity Spillovers.' Papers in Regional Science, 83, 699-722.

Driffield, N., Love, J. and Taylor, K. (2009) 'Productivity and Labour Demand Effects of Inward and Outward Foreign Direct Investment on UK Industry.' The Manchester School, 77, 171-203.

Figini, P. and Gorg, H. (1999) 'Multinational Companies and Wage Inequality in the Host Country: The case of Ireland.' Weltwirtschaftliches Archiv, 134, 594-612. 
Girma, S and Görg, H. (2007) 'Evaluating the Foreign Ownership Wage Premium using a Difference-in-differences Matching Approach.' Journal of International Economics, 72, 97-112.

Girma, S., Greenaway, D. and Wakelin, K. (2001) 'Wages, Productivity and Foreign Ownership in UK Manufacturing.' Scottish Journal of Political Economy, 48, 119-33.

Görg, H. and Strobl, E. (2002) 'Multinational Companies and Indigenous Development: An Empirical Analysis.' European Economic Review, 46, 1305-22.

Gosling, A., Machin, S. and Meghir, C. (2000) 'The Changing Distribution of Male Wages in the UK.' Review of Economic Studies, 67, 635-66.

Griffith, R. and Simpson, H. (2001) 'Characteristics of Foreign-owned Firms in British Manufacturing.' IFS working paper, WP01/10.

Groshen, E.L. (1991) 'Sources of Intra-industry Wage Dispersion: How much do Employers Matter?' Quarterly Journal of Economics, 106, 869-84.

Haskel, J. and Heden, Y. (1999) 'Computers and the Demand for Skilled Labour: Industry and Establishment Level Panel Evidence for the UK.' Economic Journal, 109, C68C79.

Hijzen, A., Görg, H. and Hine, R. C. (2005) 'International Outsourcing and the Skill Structure of Labour Demand in the United Kingdom.' Economic Journal, 115, 860-78.

Javorcik, B. and Spatareanu, M. (2005) 'Do Foreign Investors Care about Labor Market Regulations?' Rutgers University Newark Working Paper \#2005-005

Katz, L. and Autor, D. (1999) 'Changes in the Wage Structure and Earnings Inequality.' In O. Ashenfelter and D. Card (Eds.), Handbook of Labor Economics: Volume 3A. Elsevier Science, Amsterdam, The Netherlands.

Lang, K. (1991) 'Persistent Wage Dispersion and Involuntary Unemployment.' Quarterly Journal of Economics, 106, 181-202.

Machin, S. and Van Reenen, J. (1998) 'Technology and Changes in Skill Structure: Evidence from Seven OECD Countries.' Quarterly Journal of Economics, 113, 1215-44.

Montgomery, J.D. (1991) 'Equilibrium Wage Dispersion and Inter-industry Wage Differentials.' Quarterly Journal of Economics, 106, 163-79.

Mortensen, D. (2009) 'Wage Dispersion in the Search and Matching Model with Intra-firm Bargaining.' NBER Working Paper 15033.

Postel-Vinay, F. and Robin, J-M. (2002) 'Equilibrium Wage Dispersion with Worker and Employer Heterogeneity.' Econometrica, 70, 2295-350. 
Rodriguez-Clare A. (1996) 'Multinationals, Linkages and Economic Development.' American Economic Review, 86, 852-73.

Smarzynska-Javorcik, B (2004) 'Does Foreign Direct Investment Increase the Productivity of Domestic Firms? In Search of Spillovers through Backward Linkages.' The American Economic Review, 94, 605-27.

Sutton, J. (1996). 'Technology and Market Structure.' European Economic Review, 40, 51130.

Sutton, J. (1998). Technology and market structure: Theory and history. London: MIT Press.

Taylor, K. and N. Driffield (2005) 'Wage Inequality and the Role of Multinationals: Evidence from UK Panel Data.' Labour Economics, 12, 223-49.

Taylor, K. (2006) 'UK Wage Inequality: An Industry and Regional Perspective.' LABOUR: Review of Labour Economics and Industrial Relations, 20, 91-124.

Wang, Jian-Ye and Blomstrom, M (1992) 'Foreign Investment and Technology Transfer: A Simple Model.' European Economic Review, 36, 137-55.

Weitzman, M.L. (1989) 'A Theory of Wage Dispersion and Job Market Segmentation.' Quarterly Journal of Economics, 104, 121-37.

Zhao, L. (1998) 'The Impact of Foreign Direct Investment on Wages and Employment.' Oxford Economic Papers, 50,284-321. 
Table 1: Wage Inequality Estimations (1980-95)

Dependent Variable: Log of share of skilled wages in total wage bill. GMM-IV estimation

\begin{tabular}{|c|c|c|c|c|}
\hline & $\begin{array}{c}\text { Model 1: } \\
\text { baseline Model }\end{array}$ & $\begin{array}{l}\text { Model } 2 \text { : adding } \\
\text { Trade \& } \\
\text { Technology } \\
\text { Effects }\end{array}$ & $\begin{array}{l}\text { Model 3: } \\
\text { distinguishing } \\
\text { between assisted } \\
\text { areas and non- } \\
\text { assisted areas. }\end{array}$ & $\begin{array}{l}\text { Model } 4: \text { assisted } \\
\text { areas and non-assisted } \\
\text { areas and including } \\
\text { Trade \& Technology } \\
\text { Effects }\end{array}$ \\
\hline $\mathrm{K}$ & $\begin{array}{l}0.001 \\
(0.16) \\
\end{array}$ & $\begin{array}{l}0.001 \\
(0.15) \\
\end{array}$ & $\begin{array}{l}0.001 \\
(0.16) \\
\end{array}$ & $\begin{array}{l}0.001 \\
(0.16) \\
\end{array}$ \\
\hline Q & $\begin{array}{c}0.122 * * * \\
(4.17)\end{array}$ & $\begin{array}{c}0.123 * * * \\
(4.08)\end{array}$ & $\begin{array}{c}0.125 * * * \\
(4.27) \\
\end{array}$ & $\begin{array}{c}0.124 * * * \\
(4.16)\end{array}$ \\
\hline MKT_SHARE & $\begin{array}{c}-0.075^{* * * *} \\
(-2.93)\end{array}$ & $\begin{array}{c}-0.074 * * * \\
(-2.85)\end{array}$ & $\begin{array}{c}-0.077 * * * \\
(-3.03) \\
\end{array}$ & $\begin{array}{c}-0.076^{* * * *} \\
(-2.93) \\
\end{array}$ \\
\hline HERFINDAHL & $\begin{array}{c}0.082 * * * \\
(6.25)\end{array}$ & $\begin{array}{c}0.082 * * * \\
(6.12)\end{array}$ & $\begin{array}{c}0.084 * * * \\
(6.42) \\
\end{array}$ & $\begin{array}{c}0.083 * * * \\
(6.24) \\
\end{array}$ \\
\hline$(F D I)_{i r t-1}$ & $\begin{array}{l}-0.024 \\
(-1.26)\end{array}$ & $\begin{array}{l}-0.023 \\
(-1.18)\end{array}$ & $\begin{array}{c}-0.052 * * \\
(-1.93)\end{array}$ & $\begin{array}{l}-0.048^{*} \\
(-1.75)\end{array}$ \\
\hline$(F D I)_{i s t-1}$ & $\begin{array}{l}0.026 \\
(1.34)\end{array}$ & $\begin{array}{l}0.024 \\
(1.25)\end{array}$ & $\begin{array}{l}0.057 * * * \\
(2.13)\end{array}$ & $\begin{array}{l}0.052^{*} \\
(1.92)\end{array}$ \\
\hline$\left(B W D_{-} F D I\right)_{j r t-1}$ & $\begin{array}{l}0.030 \\
(1.33)\end{array}$ & $\begin{array}{l}0.027 \\
(1.20)\end{array}$ & $\begin{array}{c}0.075^{* * *} \\
(2.32)\end{array}$ & $\begin{array}{l}0.070^{* *} \\
(2.13)\end{array}$ \\
\hline$\left(F W D_{-} F D I\right)_{j r t-1}$ & $\begin{array}{l}0.003 \\
(0.22)\end{array}$ & $\begin{array}{l}0.004 \\
(0.26)\end{array}$ & $\begin{array}{l}-0.010 \\
(-0.52) \\
\end{array}$ & $\begin{array}{l}-0.009 \\
(-0.50) \\
\end{array}$ \\
\hline$\left(B W D_{-} F D I\right)_{j s t-1}$ & $\begin{array}{l}-0.040^{*} \\
(-1.88)\end{array}$ & $\begin{array}{l}-0.038^{*} \\
(-1.78)\end{array}$ & $\begin{array}{c}-0.089 * * * \\
(-2.82)\end{array}$ & $\begin{array}{c}-0.085^{* * *} \\
(-2.65)\end{array}$ \\
\hline$\left(F W D_{-} F D I\right)_{j s t-1}$ & $\begin{array}{l}0.008 \\
(0.55) \\
\end{array}$ & $\begin{array}{l}0.008 \\
(0.58) \\
\end{array}$ & $\begin{array}{l}0.022 \\
(1.23) \\
\end{array}$ & $\begin{array}{l}0.023 \\
(1.27) \\
\end{array}$ \\
\hline R\&D_INTENSE_1 & & $\begin{array}{l}0.001 \\
(0.27)\end{array}$ & & $\begin{array}{l}0.000 \\
(0.15) \\
\end{array}$ \\
\hline IMP_INTENSE & & $\begin{array}{l}-0.016 \\
(-1.02) \\
\end{array}$ & & $\begin{array}{l}-0.011 \\
(-0.69)\end{array}$ \\
\hline EXP_INTENSE & & $\begin{array}{l}0.014 \\
(0.96) \\
\end{array}$ & & $\begin{array}{l}0.010 \\
(0.65) \\
\end{array}$ \\
\hline$(F D I)_{i r t-1 \_a s s i s t}$ & & & $\begin{array}{l}0.062 \\
(1.63)\end{array}$ & $\begin{array}{l}0.055 \\
(1.43)\end{array}$ \\
\hline$(F D I)_{i s t-1 \text { _assist }}$ & & & $\begin{array}{l}-0.069^{*} \\
(-1.83) \\
\end{array}$ & $\begin{array}{l}-0.061 \\
(-1.61) \\
\end{array}$ \\
\hline$\left(B W D D_{-} F D I\right)_{j r t-1 \_}$assist & & & $\begin{array}{c}-0.099^{* *} \\
(-2.37) \\
\end{array}$ & $\begin{array}{c}-0.092^{* *} \\
(-2.20) \\
\end{array}$ \\
\hline$\left(F W D D_{-} F D I\right)_{j r t-1}$ assist & & & $\begin{array}{l}0.027 \\
(0.99) \\
\end{array}$ & $\begin{array}{l}0.028 \\
(1.01) \\
\end{array}$ \\
\hline$\left(B W D D_{-} F D I\right)_{j s t-1 \text { assist }}$ & & & $\begin{array}{l}0.108 * * * \\
(2.60)\end{array}$ & $\begin{array}{c}0.101^{* *} \\
(2.42)\end{array}$ \\
\hline$\left(F W D \_F D I\right)_{j s t-1}$ assist & & & $\begin{array}{l}-0.034 \\
(-1.23)\end{array}$ & $\begin{array}{l}-0.035 \\
(-1.27)\end{array}$ \\
\hline TIME & $\begin{array}{c}0.003 * * * \\
(4.07) \\
\end{array}$ & $\begin{array}{c}0.003 * * * \\
(3.82) \\
\end{array}$ & $\begin{array}{c}0.004 * * * \\
(4.15) \\
\end{array}$ & $\begin{array}{c}0.003^{* * * *} \\
(3.89) \\
\end{array}$ \\
\hline $\begin{array}{l}\text { Hansen J } \\
\chi^{2}(p-\text { value })\end{array}$ & $\begin{array}{c}0.114 \\
(0.944)\end{array}$ & $\begin{array}{c}0.250 \\
(0.882)\end{array}$ & $\begin{array}{c}0.140 \\
(0.932)\end{array}$ & $\begin{array}{c}0.274 \\
(0.8721)\end{array}$ \\
\hline $\mathrm{R}^{2}$ & 0.17 & 0.17 & 0.17 & 0.17 \\
\hline \# of Observations & 30,338 & 29,925 & 30,338 & 29,925 \\
\hline \# of Establishments & 7,760 & 7,676 & 7,760 & 7,676 \\
\hline
\end{tabular}

Notes: The numbers in parentheses are robust $t$ values. Standard errors adjusted for clustering (based on plant identifier). All regressions include a constant as well as 2-digit industry dummies.

$* * *$ significant at $1 \%$;** significant at $5 \%$; significant at $10 \%$. 
Table 2: Tests for equivalence of coefficients across assisted and nonassisted areas

\begin{tabular}{l|l|l}
\hline \hline$\underline{\text { Model 3 }}$ & $\chi^{2}(1)$ & p value \\
\hline$\left(B W D_{-} F D I\right)_{j t t-1}$ & 6.34 & 0.0118 \\
\hline$\left(B W D_{-} F D I\right)_{j s t-1}$ & 8.28 & 0.0040 \\
\hline$\left(F W D_{-} F D I\right)_{j s t-1}$ & 1.80 & 0.1793 \\
\hline Model 4 & & \\
\hline$\left(B W D_{-} F D I\right)_{j r t-1}$ & 5.38 & 0.0204 \\
\hline$\left(B W D_{-} F D I\right)_{j s t-1}$ & 7.22 & 0.0072 \\
\hline$\left(F W D_{-} F D I\right)_{j s t-1}$ & 1.91 & 0.1670 \\
\hline \hline
\end{tabular}


Table 3: GMM-IV Estimations (1980-95)

\begin{tabular}{|c|c|c|c|c|}
\hline & $\begin{array}{l}\text { Skilled } \\
\text { Wages }\end{array}$ & $\begin{array}{l}\text { Unskilled } \\
\text { Wages }\end{array}$ & $\begin{array}{l}\text { Skilled } \\
\text { Wages }\end{array}$ & $\begin{array}{l}\text { Unskilled } \\
\text { Wages }\end{array}$ \\
\hline $\mathrm{K}$ & $\begin{array}{l}0.003 \\
(0.69) \\
\end{array}$ & $\begin{array}{l}0.001 \\
(0.32) \\
\end{array}$ & $\begin{array}{l}0.003 \\
(0.69) \\
\end{array}$ & $\begin{array}{l}0.001 \\
(0.32) \\
\end{array}$ \\
\hline Q & $\begin{array}{l}0.809 * * * \\
(21.71) \\
\end{array}$ & $\begin{array}{l}0.631 * * * \\
(17.46)\end{array}$ & $\begin{array}{l}0.812^{* * * *} \\
(21.90)\end{array}$ & $\begin{array}{l}0.630 * * * \\
(17.44)\end{array}$ \\
\hline MKT_SHARE & $\begin{array}{l}0.071^{* *} \\
(2.20)\end{array}$ & $\begin{array}{l}0.181 * * * \\
(5.81)\end{array}$ & $\begin{array}{l}0.068^{* *} \\
(2.11)\end{array}$ & $\begin{array}{l}0.182 * * * \\
(5.84)\end{array}$ \\
\hline HERFINDAHL & $\begin{array}{l}-0.037 * * \\
(-2.23)\end{array}$ & $\begin{array}{l}-0.159 * * * \\
(-9.81)\end{array}$ & $\begin{array}{l}-0.034 * * \\
(-2.10)\end{array}$ & $\begin{array}{l}-0.160 * * * \\
(-9.85)\end{array}$ \\
\hline$(F D I)_{i r t-1}$ & $\begin{array}{l}-0.011 \\
(-0.51)\end{array}$ & $\begin{array}{l}0.010 \\
(0.43)\end{array}$ & $\begin{array}{l}-0.034 \\
(-1.16)\end{array}$ & $\begin{array}{l}0.019 \\
(0.55)\end{array}$ \\
\hline$(F D I)_{i s t-1}$ & $\begin{array}{l}0.012 \\
(0.55)\end{array}$ & $\begin{array}{l}-0.012 \\
(-0.52)\end{array}$ & $\begin{array}{l}0.040 \\
(1.37)\end{array}$ & $\begin{array}{l}-0.025 \\
(-0.73) \\
\end{array}$ \\
\hline$\left(B W D_{-} F D I\right)_{j r t-1}$ & $\begin{array}{l}-0.029 \\
(-1.22)\end{array}$ & $\begin{array}{l}-0.065 * * * \\
(-2.72)\end{array}$ & $\begin{array}{l}0.019 \\
(0.60) \\
\end{array}$ & $\begin{array}{l}-0.082 * * \\
(-2.05)\end{array}$ \\
\hline$\left(F W D_{-} F D I\right)_{j r t-1}$ & $\begin{array}{l}0.025 \\
(1.42) \\
\end{array}$ & $\begin{array}{l}0.021 \\
(1.18) \\
\end{array}$ & $\begin{array}{l}0.006 \\
(0.28) \\
\end{array}$ & $\begin{array}{l}0.025 \\
(1.09) \\
\end{array}$ \\
\hline$\left(B W D_{-} F D I\right)_{j s t-1}$ & $\begin{array}{l}-0.006 \\
(-0.29) \\
\end{array}$ & $\begin{array}{l}0.044^{*} \\
(1.91)\end{array}$ & $\begin{array}{l}-0.055^{*} \\
(-1.80) \\
\end{array}$ & $\begin{array}{l}0.066^{*} \\
(1.68) \\
\end{array}$ \\
\hline$\left(F W D_{-} F D I\right)_{j s t-1}$ & $\begin{array}{l}0.010 \\
(0.60)\end{array}$ & $\begin{array}{l}-0.001 \\
(-0.04) \\
\end{array}$ & $\begin{array}{l}0.026 \\
(1.24)\end{array}$ & $\begin{array}{l}-0.008 \\
(-0.36) \\
\end{array}$ \\
\hline R\&D_INTENSE_1 & $\begin{array}{l}0.008 * * \\
(2.08) \\
\end{array}$ & $\begin{array}{l}0.007 * \\
(1.76) \\
\end{array}$ & $\begin{array}{l}0.008^{* *} \\
(1.96) \\
\end{array}$ & $\begin{array}{l}0.007 * \\
(1.84) \\
\end{array}$ \\
\hline IMP_INTENSE & $\begin{array}{l}-0.054 * * * \\
(-2.93)\end{array}$ & $\begin{array}{l}-0.030^{*} \\
(-1.68) \\
\end{array}$ & $\begin{array}{l}-0.047 * * \\
(-2.54) \\
\end{array}$ & $\begin{array}{l}-0.031^{*} \\
(-1.70) \\
\end{array}$ \\
\hline EXP_INTENSE & $\begin{array}{l}0.047 * * * \\
(2.65)\end{array}$ & $\begin{array}{l}0.026 \\
(1.55)\end{array}$ & $\begin{array}{l}0.040^{* * *} \\
(2.29)\end{array}$ & $\begin{array}{l}0.026 \\
(1.56)\end{array}$ \\
\hline$(F D I)_{i r t-1 \text { assist }}$ & & & $\begin{array}{l}0.050 \\
(1.22)\end{array}$ & $\begin{array}{l}-0.019 \\
(-0.40)\end{array}$ \\
\hline$(F D I)_{i s t-1 \text { _assist }}$ & & & $\begin{array}{l}-0.060 \\
(-1.47)\end{array}$ & $\begin{array}{l}0.028 \\
(0.60)\end{array}$ \\
\hline$\left(B W D \_F D I\right)_{j r t-1-a s s i s t}$ & & & $\begin{array}{l}-0.102 * * \\
(-2.33)\end{array}$ & $\begin{array}{l}0.034 \\
(0.63)\end{array}$ \\
\hline$\left(F W D \_F D I\right)_{j r t-1}$ assist & & & $\begin{array}{l}0.039 \\
(1.14)\end{array}$ & $\begin{array}{l}-0.007 \\
(-0.23)\end{array}$ \\
\hline$\left(B W D_{-} F D I\right)_{j s t-1}$ assist & & & $\begin{array}{l}0.104 * * \\
(2.39)\end{array}$ & $\begin{array}{l}-0.047 \\
(-0.87)\end{array}$ \\
\hline$\left(F W D \_F D I\right)_{j s t-1 \_ \text {assist }}$ & & & $\begin{array}{l}-0.036 \\
(-1.09)\end{array}$ & $\begin{array}{l}0.016 \\
(0.52)\end{array}$ \\
\hline TIME & $\begin{array}{l}0.059 * * * \\
(56.73)\end{array}$ & $\begin{array}{l}0.051 * * * \\
(48.12)\end{array}$ & $\begin{array}{l}0.059 * * * \\
(57.00)\end{array}$ & $\begin{array}{l}0.051 * * * \\
(53.37)\end{array}$ \\
\hline $\mathrm{R}^{2}$ & 0.82 & 0.80 & 0.82 & 0.80 \\
\hline \# of Observations & 29,518 & 29,440 & 29,518 & 29,440 \\
\hline $\begin{array}{l}\text { Anderson canon. Corr. (identification/IV } \\
\text { relevance test) } \\
\text { p-value }\end{array}$ & 0.000 & 0.000 & 0.000 & 0.000 \\
\hline $\begin{array}{l}\text { Hansen J (over-identification instrument } \\
\text { test) p-value }\end{array}$ & 0.256 & 0.036 & 0.265 & 0.037 \\
\hline
\end{tabular}

Notes: Figures in parentheses are z- values. $* * *$ means significant at 1\%; $* *$ means significant at 5\%;

* means significant at $10 \%$. All variables (except TIME) are in logs. 
Table A1: Summary Statistics of Domestic Establishments

\begin{tabular}{|c|c|c|c|c|c|}
\hline Variable & Definition & 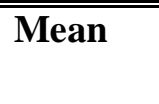 & $\begin{array}{l}\text { Std. } \\
\text { Deviation }\end{array}$ & "Minimum & Maximum \\
\hline$\frac{W_{S K}}{W_{S K}+W_{U N S K}}$ & $\begin{array}{l}\text { Share of Skilled Wages in Total Wage } \\
\text { Bill }\end{array}$ & -1.163 & 0.570 & -6.516 & 0 \\
\hline $\mathrm{K}$ & Real Capital Stock & 7.712 & 1.532 & -3.344 & 15.332 \\
\hline $\mathrm{Q}$ & $\begin{array}{l}\text { Total Manufacturing Real Gross Output. } \\
\text { Deflated by 4-digit producer price index }\end{array}$ & 8.559 & 1.488 & -5.925 & 15.850 \\
\hline MKT_SHARE & $\begin{array}{l}\text { Market Share. Measured as plant output } \\
\text { as a share of 4-digit industry output. }\end{array}$ & -5.548 & 1.611 & -15.457 & 0 \\
\hline HERFINDAHL & $\begin{array}{l}\text { Herfindahl-Hirschman Index. Sum of the } \\
\text { squares of market shares }\end{array}$ & -3.508 & 0.924 & -5.251 & 0 \\
\hline R\&D_INTENSE & $\begin{array}{l}\mathrm{R} \& \mathrm{D} \text { expenditure as a ratio of total } \\
\text { manufacturing real gross output }\end{array}$ & 0.010 & 0.249 & -6.913 & 12.498 \\
\hline IMP_INTENSE & $\begin{array}{l}\text { Total manufacturing imports as ratio of } \\
\text { total manufacturing real gross output. }\end{array}$ & -0.022 & 0.290 & -11.109 & 7.763 \\
\hline EXP_INTENSE & $\begin{array}{l}\text { Total manufacturing exports as ratio of } \\
\text { total manufacturing real gross output }\end{array}$ & -0.023 & 0.303 & -10.625 & 7.554 \\
\hline$(F D I)_{i r t-1}$ & Intra industry FDI in the same region & 0.130 & 0.208 & 0 & 1 \\
\hline$(F D I)_{i s t-1}$ & Intra industry FDI in outside region & $2.68 \mathrm{e}-06$ & $9.76 \mathrm{e}-06$ & 0 & 0.0006 \\
\hline$\left(B W D_{-} F D I\right)_{j r t-1}$ & $\begin{array}{l}\text { Inter industry backward FDI in the } \\
\text { same region }\end{array}$ & 0.0003 & 0.004 & 0 & 0.2271 \\
\hline$\left(F W D_{-} F D I\right)_{j r t-1}$ & $\begin{array}{l}\text { Inter industry forward FDI in the same } \\
\text { region }\end{array}$ & 0.0003 & 0.0047 & 0 & 0.2021 \\
\hline$\left(B W D_{-} F D I\right)_{j s t-1}$ & $\begin{array}{l}\text { Inter industry backward FDI outside } \\
\text { region }\end{array}$ & $1.32 \mathrm{e}-08$ & $3.27 \mathrm{e}-07$ & 0 & 0.00002 \\
\hline$\left(F W D_{-} F D I\right)_{j s t-1}$ & $\begin{array}{l}\text { Inter industry forward FDI outside } \\
\text { region }\end{array}$ & $1.31 \mathrm{e}-08$ & $3.49 \mathrm{e}-07$ & 0 & 0.00002 \\
\hline
\end{tabular}

NOTE: All variables (except FDI variables) are in logs. The FDI terms are the share of foreign owned employment in a given sector, weighted (where appropriate) by the input-output coefficients to capture links between sectors. As many inputoutput coefficients are close to zero, this leads to very small values for the intra- and inter-industry FDI terms. 
Table A2: Regional Distribution of Horizontal FDI (Employment Share)

\begin{tabular}{l|c|c|c|c}
\hline \hline \multicolumn{1}{c|}{ Region } & Mean & $\begin{array}{c}\text { Std. } \\
\text { Deviation }\end{array}$ & Minimum & Maximum \\
\hline East Anglia & 0.153 & 0.190 & 0 & 0.975 \\
South East & 0.137 & 0.229 & 0 & 0.985 \\
East Midlands & 0.141 & 0.220 & 0 & 1 \\
West Midlands & 0.094 & 0.164 & 0 & 0.947 \\
South West & 0.086 & 0.161 & 0 & 0.969 \\
Yorkshire \& Humberside & 0.098 & 0.158 & 0 & 0.923 \\
North West & 0.105 & 0.160 & 0 & 0.986 \\
North & 0.153 & 0.243 & 0 & 1 \\
\hline Wales & 0.170 & 0.258 & 0 & 1 \\
Scotland & 0.166 & 0.242 & 0 & 1 \\
\hline \hline
\end{tabular}

The maximum values relate to sector/ region specific cases where all of the sector in that region is foreign owned. 